\title{
Hepatitis C Virus Core Protein: An Update on Its Molecular Biology, Cellular Functions and Clinical Implications
}

\author{
M. Irshad Indranil Dhar \\ Clinical Biochemistry Division, Department of Laboratory Medicine, All India Institute of Medical Sciences, \\ New Delhi, India
}

\begin{abstract}
Key Words
Core protein - Hepatitis C virus - Hepatocellular carcinoma • Apoptosis
\end{abstract}

\begin{abstract}
The present review article is an update on various features of hepatitis $\mathrm{C}$ virus (HCV) core protein including its molecular biology, role in HCV replication, involvement in HCV pathogenesis, etiological role in hepatocellular carcinogenesis, significance in diagnosis and vaccination against HCV infection. Core protein is a structural protein of HCV virus and has only recently been characterized. It was found to play a major role in HCV-induced viral hepatitis. Although published information shows a lot about the clinical significance of HCV core protein, several studies are still needed to demonstrate its exact significance in viral biology and underlying HCV pathogenesis.

Copyright $\odot 2006$ S. Karger AG, Basel
\end{abstract}

\section{Introduction}

Hepatitis $\mathrm{C}$ virus (HCV) causes a spectrum of liver diseases ranging from an asymptomatic carrier state to hepatocellular carcinoma (HCC). HCV infection has been detected globally and poses a serious public health problem throughout the world. The majority of individuals infected with HCV fail to resolve the infection and suffer from chronic hepatitis. Infection with HCV has been identified as a leading cause of HCC in many countries around the world [1]. Evidence of an important role for HCV infection includes high seroprevalence of anti$\mathrm{HCV}$ antibodies among patients with HCC and documented progression from chronic hepatitis to cirrhosis to HCC. Most of these patients have HCV RNA present in serum as well as in liver tissue and, in many cases, within the tumor itself.

While intravenous drug use has become the main route of transmission in most industrialized countries, blood transfusion still represents a major contamination risk in developing countries where blood screening is not widely implemented. The prevalence of HCV infection in various locations around the world ranges from 0.5 to $10 \%$ [2]. It is believed that more than $70 \%$ of HCV-infected patients become chronic carriers [3] with the risk of developing cirrhosis and HCC. While HCV has infected an estimated 175 million people worldwide [4], only a minority of these benefit from antiviral therapies. The development of a vaccine is thus highly desirable.

Molecular biology of HCV has revealed that it has different structural components with diverse functions [5]. The nonstructural component of HCV, HCV core protein has attracted special attention after its characterization and various reports on its important role in HCV pathogenesis. This review is an update on HCV core protein with emphasis on its structure, cellular functions and clinical implications during HCV infection.

\section{KARGER}

Fax +4161306 1234

E-Mail karger@karger.ch

www.karger.com (c) 2006 S. Karger AG, Basel

$1011-7571 / 06 / 0156-0405 \$ 23.50 / 0$

Accessible online at:

www.karger.com/mpp
Dr. M. Irshad

Clinical Biochemistry Division, Department of Laboratory Medicine

P.O. Box 4938, A.I.I.M.S, Ansari Nagar, New Delhi 110029 (India)

Tel. +91 112658 8500/8700, Fax +91 112658 8643/8669

E-Mail drirshad54@yahoo.com 


\section{Molecular Structure}

\section{HCV Genome}

After the genome of $\mathrm{HCV}$ was cloned in 1989, this virus was classified as a new member of the Flaviviridae family $[6,7]$. HCV is reported to have 6 different genotypes and at least 30 subtypes $[8,9]$. HCV has a positive sense, single-stranded RNA genome that has a single long open reading frame flanked by $5^{\prime}$ and $3^{\prime}$ untranslated regions (UTRs). It codes for polypeptides amounting to a total of 3,000 amino acids. These are subdivided into 3-4 structural proteins at the amino-terminus (core, E1 and E2/P7) and six nonstructural proteins [NS2 (protease) NS3 (protease-helicase), NS4A (co-factor for NS3), NS4B, NS5A (serine phosphoprotein) and NS5B (RNA polymerase)] at the carboxyl terminus [5].

The presence of an internal ribosome entry site for initiation of polyprotein translation has been reported for the highly conserved 5' UTR [10]. The 3' UTR is thought to be critical for RNA replication and packaging and has been found to be essential for infectivity of HCV cDNAs [11]. The polyprotein is processed by both viral and cellular proteases into at least 10 polypeptides including structural and nonstructural proteins [12]. Between structural and nonstructural proteins, an alternative cleavage can lead to the formation of a small protein named p7 [13].

\section{HCV Core Protein Expression}

Physical association of the core protein with E1 and E2 glycoproteins, may have a role in virus morphogenesis $[14,15]$. In the absence of microsomal membranes, the core protein is synthesized as a polypeptide of $\sim 22 \mathrm{kDa}$. Simultaneously, additional polypeptides of higher molecular mass may also appear. All these represent complex oligomeric aggregates of the core protein. However, in the presence of microsomal membranes, the polypeptide profile of core is changed. This change is likely derived from a posttranslational proteolytic cleavage of the signal peptide at the carboxy terminus. Most of the core analysis reported here has been made in artificial core expression systems in the absence of a complete $\mathrm{HCV}$ replication cycle.

\section{Biophysical Characterization of the Core Protein}

Biophysical characterization of the core protein indicates that the C-terminal residues 125-179 are critical for the folding and oligomerization of the core protein. The mature core protein contains significant secondary structure and associates as a large multimer of $\sim 24$ monomers, while the C-terminally truncated core protein is unstructured and monomeric [16]. Additionally, the tryptophanrich region, previously shown to facilitate self-association in vivo, was not responsible for this interaction in vitro.

The biophysical profile of the C-terminally truncated core is different from that of the mature core protein. It implies that this truncated core may interact with viral and host-cell factors differently from the mature core protein. The lack of structure in C-terminally truncated core suggests that it is likely to recognize host macromolecules through sequence-specific interactions, while structured noncontiguous epitopes may regulate mature core protein interactions with host proteins.

It is also possible that the C-terminal deletion core proteins used to investigate host-cell interactions became structured through their interaction with nucleic acid [17, 18]. Since the core protein nonspecifically binds nucleic acid in vitro $[19,20]$, it is likely that the core protein is associated with nucleic acid in cell culture. Possibly the binding of nucleic acid to the core protein influenced the reported interactions between the C-terminal deletion core proteins and host-cell proteins or the multimerization of the core protein in cell-based systems [21, 22].

The role of the multimeric mature core protein is unknown. The formation of the 11S species of the core protein may be an intermediate in the assembly pathway. The accumulation of the core protein at the site of assembly may accelerate the formation of the capsid shell and decrease the number of additional interactions that the core protein must make upon assembly. However, results from self-assembly of the $11 \mathrm{~S}$ core protein into nucleocapsidlike particles imply that additional interactions or steps are required for the $11 \mathrm{~S}$ core proteins to form particles consistent with the morphology and size of nucleocapsids from infectious viruses [17].

\section{Role of the Core Protein in Cell Regulation and HCV Replication}

Many studies have focused on the biological effects of $\mathrm{HCV}$ core in cells, its activities on transcription regulation, signal transduction and cell-cycle regulation. The core protein is the viral nucleocapsid protein that binds and packages the viral RNA genome. Core has been shown to form multimers [21,23] and can efficiently selfassemble in vitro into nucleocapsid-like particles. In addition, core is able to interact with the envelope protein (E1) [23]. Taken together, these data suggest that core, along with the envelope proteins, forms the capsid of 
a

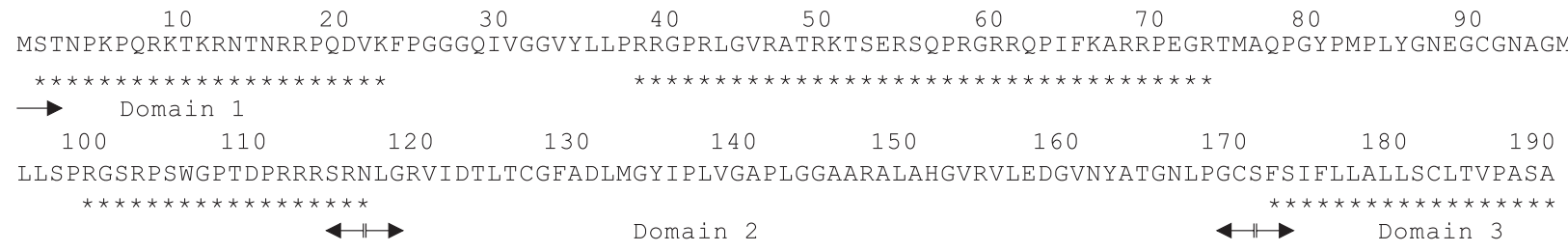

b
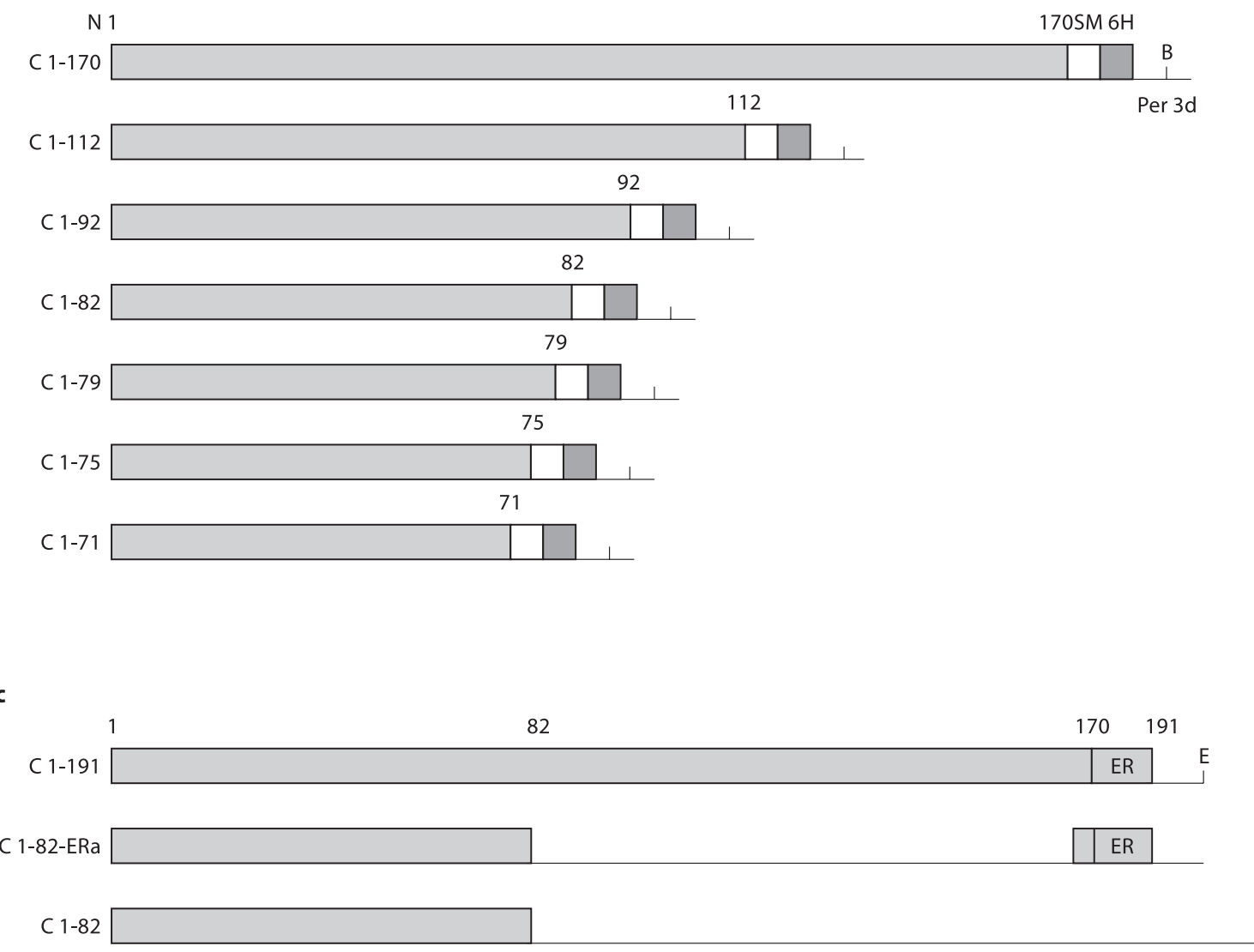

PPIC3, 5

Fig. 1. Schematic representation of HCV core protein. a Amino acid sequence of HCV core protein. HCV core protein constructs expressed in Escherichia coli (b) and Pichia pastoris (c).

HCV. Core is localized in the cytoplasm, but deletion of the C-terminal hydrophobic region causes core to translocate to the nucleus [24-26]. Core interacts with several cellular proteins including tumor necrosis factor, lym- photoxin- $\beta$ receptor $[24,27-29]$ and RNA helicases [3033]. Since full-length core is found in the cytoplasm, its role in transcriptional regulation could be through its interaction with cytoplasmic proteins and signal transduc- 
tion pathways [33-36] so as to cause the transcription or repression of nuclear genes. Simultaneously, core has been reported to regulate apoptosis [37-38], steatosis [39], tumorigenesis [40] and abnormal lipid metabolism [41].

A novel interaction between core and NS5A using the yeast two-hybrid method has been reported [42]. The minimal region of NS5A required for binding with core contains the ISDR, PKR-binding and proline-rich regions. However, it is possible that the two proteins formed a complex through other proteins. Core has been shown to be associated with lipid droplets $[43,44]$, while NS5A is localized to the perinuclear region.

The function of the core-NS5A interaction for viral assembly or replication is not clear. Core binds specifically to the 5' NCR of the HCV genome and possibly suppresses its translation [19]. Alternatively, core-NS5A may couple viral replication to viral assembly, since NS5A is likely to be involved in replication and core is the nucleocapsid protein that binds the viral RNA.

Binding between the two proteins is apparently not necessary for NS5A cleavage, as other apoptotic signals can induce NS5A cleavage [45] in the absence of core. However, cells infected with HCV will express core, which could provide an intrinsic apoptotic signal in cells infected with HCV; the level of core may not be high enough to induce programmed cell death, but other factors such as cytokine stimulation [26] and the activation of certain signal transduction pathways involving Fas signaling [46] could enhance the proapoptotic signal of core. NS5A modulates cell-cycle regulatory genes and promotes cell growth. Coexpression of NS5A with core does not reduce apoptosis. It is not evident from these observations that NS5A modulates the apoptotic effect of core.

To activate transcription, both core and the serine phosphoprotein (NS5A) need to be translocated into the nucleus. This may be made possible by the deletion of regions of NS5A and core that contain the cytoplasmic retention signal [24, 25, 47]. For NS5A, the cleavage by caspases produces $\mathrm{N}$-terminally deleted forms that can enter the nucleus and act as transcription activators. Core, when expressed in mammalian cells, is truncated at the C-terminal [48], which should remove the hydrophobic tail that localizes core to the cytoplasm. Nuclear-localized core could not be detected in immunofluorescence experiments, possibly because full-length core complexes with the truncated core and prevents the truncated core from being transported to the nucleus [48]. Fractionation methods to separate nuclear proteins from cytoplasmic proteins cannot definitively determine the presence of nuclear-localized NS5A protein as nuclear fractions are inadvertently contaminated by cytoplasmic or membrane-associated proteins. Failure to detect nuclear-localized forms of NS5A and core by immunofluorescence does not exclude the possibility that small amounts of these proteins are sufficient to affect transcription of certain genes that may lead to pathogenesis in the long term. The identification of genes that are regulated by NS5A and core individually or in combination would be of interest for the understanding of HCV-related pathology [49].

\section{Role of the Core Protein in HCV Pathogenesis}

\section{Effect of Core on Apoptosis}

Although diverse effects of the core protein on apoptosis have been reported, the underlying mechanisms are not fully understood [39]. The HCV core protein exhibits both proapoptotic or antiapoptotic actions. Modulation of apoptosis may involve binding of $\mathrm{HCV}$ core protein to the intracellular signal-transducing portion of death receptors and displacement of signaling molecules [50]. Previous studies showed that hepatocytes resemble type II cell lines, in which Fas-induced death is dependent on mitochondria [51], and that bcl-2 members act as a selective link between upstream signals and downstream death effectors [52-53]. In a study using an RNase protection assay and Southern blotting, it was demonstrated that not only $\mathrm{Bcl}-\mathrm{x}$ mRNA, but also $\mathrm{Bcl}-\mathrm{x}_{\mathrm{L}}$ protein was increased in the core-producing HepG2 cells. As $\mathrm{Bcl}-\mathrm{x}_{\mathrm{L}}$ is known to block the cleavage-mediated activation of procaspase-3, a critical downstream effector caspase in the apoptotic pathway [54-56], the core-producing HepG2 cells were considered to inhibit procaspase- 3 activation through enhanced expression of $\mathrm{Bcl}-\mathrm{x}_{\mathrm{L}}$ protein.

Although the core protein activates the NF-kB pathway $[39,57-59]$, the enhanced expression of $\mathrm{Bcl}-\mathrm{x}_{\mathrm{L}}$ by the core protein was not dependent on the NF-kB site in the $\mathrm{Bcl}-\mathrm{x}_{\mathrm{L}}$. The regulation of $\mathrm{Bcl}-\mathrm{x}_{\mathrm{L}}$ expression appears to be quite complex, and the contribution of NF-kB to this process may depend on cell type or activating stimuli. In fact, other studies failed to reveal alterations in $\mathrm{Bcl}-\mathrm{x}_{\mathrm{L}}$ transcript levels by NF-kB activation [58-62].

The Fas system is known to play an important role in liver cell injury by HCV and in the clearance of viruses [63]. The ability of the core protein to inhibit the Fas-mediated apoptotic pathway by upregulation of $\mathrm{Bcl}-\mathrm{x}_{\mathrm{L}}$ expression may help in evading host antiviral defense mech- 
anisms. It was reported that the expression of $\mathrm{Bcl}-\mathrm{x}_{\mathrm{L}}$ is high in HCC in transgenic mice [64]. Therefore, $\mathrm{Bcl}-\mathrm{x}_{\mathrm{L}^{-}}$ expressing cells by their capacity to inhibit apoptosis could account for the development of HCC in hepatitis C patients.

\section{Immunomodulatory Role of HCV Core}

The immunomodulatory role of $\mathrm{HCV}$ core protein in the inhibition of $\mathrm{T}$ cell responsiveness has characterized the effect of HCV core on T cell activation through its interaction with gClqR. Upon stimulation of human $\mathrm{PBMC}$ with either Con A or anti-CD3/CD28, it was found that HCV core inhibited the proliferation of T-lymphocytes in a dose-dependent manner. In addition, the production of IL-2 and IFN- $\gamma$ [65-67] in core-treated cells was markedly diminished, as compared with control cells. The addition of high doses of exogenous rIL-2 (50$100 \mathrm{U} / \mathrm{ml}$ ) to core-treated T-cell cultures partially restored the core-induced inhibition of $\mathrm{T}$ cell proliferation, suggesting that $\mathrm{HCV}$ core might interfere with the expression of IL-2R or its downstream signaling events. Indeed, HCV core affected the expression of high-affinity IL-2R by downregulating IL-2R $\alpha$ chain expression. Subsequent analysis of the effect of HCV core on the ERK/ MEK MAP kinase showed that HCV core inhibited the activation of ERK/MEK MAP kinase, which led to the inhibition of IL-2 and IL-2R $\alpha$ chain gene transcription. These results suggest that the impaired activation of ERK/MEK MAP kinase due to the core/gCIqR interaction inhibits the transcription of early genes involved in $\mathrm{T}$ cell activation and leads to the suppression of $\mathrm{T}$ cell responsiveness.

It is important to point out that patients chronically infected with HCV exhibit immune dysfunction with a Th2-dominant cytokine profile, while Th1 cytokines are prominent in those with self-immune $\mathrm{HCV}$ infection [68-71]. The decreased levels of Th1 cytokines in the periphery of chronic HCV patients can be recovered by treatment with IFN- $\alpha$ and ribavirin [72]. The strength and quality of both Th1 cell and CTL responses have been reported to play a crucial role in recovery from HCV infection $[73,74]$. The immunomodulatory function of $\mathrm{HCV}$ core through its interaction with the $\mathrm{gClqR}$, as described in this report, may play a critical role in the establishment of HCV persistent infection during the early viral infection by suppressing $\mathrm{T}$ cell responses including the IL- 2 and IFN- $\gamma$ production. A critical issue relating to the role of core/gClqR-induced immune suppression in chronic HCV infection is the presence of circulating core protein in the blood of $\mathrm{HCV}$-infected patients that could potentially interact with peripheral T-lymphocytes. Strikingly, it has been reported that HCV core protein was secreted from tissue culture cell lines [75], and that the circulation of free HCV core protein has been detected in the plasma of HCV-infected patients [76, 77]. The potential impact for circulating HCV core protein to suppress host immune responses of $\mathrm{HCV}$ is further supported by several reports of high levels of the core protein detected during the early stage of infection before the production of anti-core $\mathrm{Ab}[78,79]$. These studies support the views of core-induced immune suppression in HCV persistence. During the early acute phase of HCV infection, circulating core protein (i.e. core protein free of anticore $\mathrm{Ab}$ binding) could inhibit $\mathrm{T}$ cell responses by binding to the gClqR on peripheral T cells. Studies on underlying mechanisms of core/gClqR-induced immunosuppression will provide a rational basis for developing therapeutics and immunization strategies.

Experiments carried out in cell lines expressing various HCV proteins alone or in different combinations revealed that the expression of the structural region (coreE1-E2-p7) clearly impaired IFN- $\alpha$-mediated antiviral activity, indicating that the expression of the structural proteins alone may interfere with the IFN system. In cells expressing the core protein in very high levels, there was also some impairment of the antiviral response. Thus, HCV core protein has significant effects at the cellular level. On one hand it can stimulate various cell signaling pathways such as NF-kB and AP-1 [34], while at the same time it can inhibit TNF- $\alpha$-mediated signaling and regulate cell growth and apoptosis [80]. In mice, HCV core expression impaired their antiviral resistance [81], suggesting that the core protein alone may have immunosuppressive or anti-IFN activities.

\section{Role of Core in Oxidative Stress}

$\mathrm{HCV}$ core protein directly produces oxidative stress and changes in mitochondria. Several possible mechanisms could explain core-induced changes in mitochondrial function. One explanation is that the core protein alters signal transduction pathways that promote the mitochondrial permeability transition. The core protein is known to bind to the cytoplasmic domains of the lymphotoxin- $\beta$ receptor [82] and tumor necrosis factor receptor-1 [26]. Oligomerization of each of these receptors initiates a signaling cascade that involves activation of caspase-8, proteolytic activation of Bid, and translocation of activated Bid from cytosol to mitochondria. This results in mitochondrial permeability transition, release of cytochrome-C, and ultimately cellular apoptosis [83]. 
Other evidence also suggests that changes in signaling to the mitochondria are not the primary effect of the core protein. In a recent study in transgenic mice, Machida et al. [84] observed no change in caspase- 8 or Bid activation resulting from expression of $\mathrm{HCV}$ proteins in the liver. In preliminary studies, they also did not observe any effect of the core protein on the activation state or subcellular localization of Bid. This evidence suggests that core-induced ROS production is not a consequence of caspasemediated signaling to the mitochondria [43].

An alternative hypothesis is that the core protein interacts directly with mitochondria, impairing electron transport, and thereby increasing ROS production. The core protein has been previously demonstrated to be associated with the $\mathrm{ER}^{5}$ and intracellular lipid droplets [44, 75]. In the Huh-7/191-20 cells, the core protein colocalized with perinuclear mitochondria, was present in purified mitochondria and ER fractions, and was expressed in structures adjacent to the mitochondria. Immunoelectron microscopy in transgenic mice has also shown an association of the core protein with mitochondria [85]. Close interactions of ER and mitochondria have also been observed in other cells [86].

Evidence obtained from studies by Okuda et al. [87] does not directly show a functional effect of the core protein on mitochondria, but it suggest that mitochondria are the major spheres of ROS because DPI, an inhibitor of electron transport in flavoenzymes, completely abolished the core-induced increment in ROS content. This inhibitor, which was not toxic to their cells under these conditions, blocks mitochondrial complex I at a proximal site and has been shown to prevent almost all mitochondrial ROS production [88]. DPI can also inhibit ROS production from microsomal NADPH oxidase. Two other mitochondrial electron transport inhibitors, rotenone, a distal complex I inhibitor, and antimycin A, a complex III inhibitor, increase mitochondrial ROS production by themselves [89] and thus could not provide information on core-induced ROS.

The observations of Okuda et al. [87] suggest a new model for the pathogenesis of chronic hepatitis C. An increased abundance of ROS occurs as a direct result of core protein expression. This is likely to further impair mitochondrial electron transport, amplifying the effect of core on the mitochondria and sensitizing cells to other oxidative insults. Such a positive feedback effect of ROS on mitochondrial ROS generation is documented [90]. Most $\mathrm{T}$ cells of the body use a number of antioxidant mechanisms to respond to these circumstances, including induction of antioxidant proteins that contribute to cell survival. Antioxidant gene expression could explain some of the divergent effects of the core protein on apoptosis seen in other experiments [37, 46, 84]. Different $\mathrm{T}$ cells are likely to respond to the core-induced ROS increase in different ways. In the Huh-7/191-20 line, there is a dramatic induction of antioxidant gene expression. The core protein has been shown to activate antiapoptotic factors such as NF-kB [34]. This could have a net effect that suppresses apoptosis. In cells that fail to activate antioxidant genes or NF-kB, core protein-induced ROS production may sensitize cells to apoptosis. What is consistent is that core protein expression increases cellular ROS. This interpretation is further supported by the recent report of Moriya et al. [91], who have demonstrated that HCV core protein causes a state of oxidative stress in transgenic mice.

As a consequence of chronic oxidative stress, there is a reduction in mitochondrial metabolic processes, which might contribute to the development of steatosis by inhibition of $\beta$-oxidation and oxidative damage to both mitochondrial and chromosomal DNA. The combination of oxidative DNA damage and suppression of apoptosis favors the development of HCC. Recent observations in transforming growth factor $\alpha / c$-myc mice show that chronic oxidative stress promotes hepatic tumor formation and that this can be prevented by antioxidant therapy [92]. The consequences of impaired mitochondrial function and abnormal ROS generation would be exacerbated by the immune-mediated inflammatory process present in patients with chronic hepatitis $\mathrm{C}$, and the additional oxidant load it would present to the $\mathrm{HCV}$-infected liver.

The hypothesis that HCV core protein stimulates prooxidant production has also been supported by the recent studies of Okuda et al. [87], who demonstrated increased ROS in Huh-7- or HeLa cyclin-inducible expression system. Acute core expression was accompanied by increased lipid peroxidation and induction of some antioxidant enzymes [93]. Although the data were collected from cultured cells which probably overexpress HCV core as compared to infected human liver, the amount of viral replication and viral proteins produced during $\mathrm{HCV}$ infection in vivo is currently unclear $[94,95]$. On the other hand, available evidence suggests that the core protein promotes oxidative stress in vivo and the consequences of this stress cause hepatic injury. Transgenic mice that constitutively express HCV core protein showed increased hepatic lipid peroxide species, steatosis, and HCC [90]. Hepatic steatosis and development of HCC are highly associated with HCV infection in humans [96]. Lerat et al. 
[97] reported that transgenic mice that express either HCV structural genes or full-length HCV gene sequences also develop steatosis and HCC. The transgenic mice studies suggest that individual HCV proteins, such as core, manifest extraviral activities in vivo. Collectively, the in vitro and in vivo data imply that the prooxidant actions of core may have a mechanistic role in the pathology of the virus and should be studied further.

\section{Role of HCV Core in Hepatocellular Carcinogenesis}

The core protein of HCV has been shown to induce HCC in transgenic mice and has been suggested to play a central role in the development of HCC in chronic hepatitis C [85]. However, it still remains unclear how the core protein operates in the development of HCC: modulation of certain cellular gene products such as helicase lymphotoxin B receptor or dead box protein [59] as shown in cell culture system, may contribute to hepatocarcinogenesis. Induction of oxidative stress is also a possibility. Few studies found an age-dependent increase in oxidative stress in the livers of transgenic mice that develop HCC in the absence of inflammation as a consequence of the core protein [90].

Hepatic steatosis is a risk factor for HCC in patients with chronic HCV infection [98]. Prevalence of hepatic steatosis ranges from 31 to $72 \%$. The pathogenesis of hepatic steatosis in patients with chronic HCV infection has been postulated recently. Both in vitro and in vivo studies have shown that HCV core protein expression either in cell culture or in transgenic mice led to the development of hepatic steatosis, contributing to carcinogenesis [43, 44]. Steatosis induced by HCV core protein, predisposes to lipid peroxidation and excess free radical activity with the potential risk of genomic mutations. Marreto et al. [99] reported that nonalcoholic fatty liver disease may be a common underlying liver disease in patients with HCC in the US. All these reports support the view that hepatic steatosis plays a role in hepatocarcinogenesis in patients with chronic HCV infection. The possible mechanism is based on the fact that the core protein interacts directly with mitochondria impairing electron transport and thus increasing ROS production. Core is also reported to be associated with ER [43] and lipid droplets [44]. The consequence of oxidative stress is the reduction in mitochondrial metabolic processes, which might contribute to the development of steatosis by inhibition of $\beta$-oxidation and oxidative damage to both mitochondria and chromosomal DNA.
HCV core also modulates a number of cellular regulatory functions. In fact, HCV core protein has been found to modulate the expression of the cyclin-dependent inhibitor $\mathrm{p} 21^{\mathrm{WAF} 1}$ and to promote both apoptosis and cell proliferation through its physical interaction with p53 [99-102].

The core protein is produced as an innate form (amino acids 1-191) and following processing produces a mature form (amino acids 1-173). The innate form regulates subcellular localization of the mature expression, and the mature form in the nucleus suppresses the $\mathrm{p} 21^{\mathrm{WAF} 1} \mathrm{ex}-$ pression. Thus, the core protein in the cytoplasm increases the amount of $\mathrm{p} 21^{\mathrm{WAF} 1}$ via activating $\mathrm{p} 53$, and the core protein in the nucleus decreases the amount of $\mathrm{p} 21^{\mathrm{WAF}}$ by a p53-independent pathway. The regulation of $\mathrm{p} 21^{\mathrm{WAF} 1}$ expression by the core protein via subcellular localization might decide the fate of infected cells either towards proliferation or apoptosis. Thus, the innate form is not only a precursor of the mature form but also a regulator of the localization and functions of the core protein $[102,103]$.

In addition, HCV core protein has also been seen to regulate p73, a member of the family of p53. p73 is involved in neurogenesis and natural immune response and seems strongly involved in malignancy acquisition and maintenance process [104]. p73/core interaction results in the nuclear translocation of $\mathrm{HCV}$ core protein either in the presence of the p73- $\alpha$ or p73- $\beta$ tumor suppressor proteins. In addition, the interaction with $\mathrm{HCV}$ core protein prevents $p 73-\alpha$-, but not $p 73-\beta$-dependent cell growth arrest in a p53-dependent manner. HCV core protein may directly influence various p73 functions, thus playing a role in $\mathrm{HCV}$ pathogenesis [105].

\section{Role of Core in Vaccination against HCV}

HCV nucleocapsid (core) may represent a valuable component in the development of a vaccine as it is the most conserved viral antigen. Results of nucleotide and deduced amino acid sequence analysis reveals $93 \%$ nucleotide and 96\% amino acid core sequence homology [106].

The core protein has been shown to induce both a humoral and a cellular-mediated response in the natural infection: (a) anticore antibodies are among the first antibodies to appear during the acute phase of infection. An increase in IgG1 isotype concomitant with a decrease in IgG3 isotype has been observed during the development of chronicity [107]; (b) core-specific peripheral blood CD4+ T cell proliferative responses are often correlated 
with viral remission in IFN- $\alpha$-treated chronic carriers [107-108], and (c) intrahepatic core-specific CTL cells were found associated with lower levels of viremia and more active liver disease in chronic patients [109].

Earlier studies using a full-length core sequence under the control of a cytomegalovirus promoter have revealed a rather limited immunogenicity of $\mathrm{HCV}$ core when introduced into a host in the form of naked DNA. The antibody seroconversion rate and the vigor of induced CTL responses in mice reached optimal values of 40 and $30 \%$ (for an E:T ratio of 100:1), respectively [110, 111]. Different strategies have subsequently been followed to try and optimize such responses. As previously described for the envelope glycoproteins, the use of plasmids containing truncated sequences of core expressed in fusion with the HbsAg has been tested $[112,113]$. HBV-HCV chimeras have been constructed, either by insertion of HCV sequences within the coding sequence of the preS2 gene $[114,115]$ or downstream from the $S$ gene [112]. Major et al. [115] demonstrated expression of both HCV and HBV antigens in the cytoplasms and supernatants of transiently transfected cells, but Geissler et al. [113] could not document viral antigen secretion in supernatants. In both studies, seroconversion rates and antibody titers were systematically found to be lower for the nonchimeric core-expression plasmid compared with chimeric ones, while up to $60-100 \%$ rates and at least one log increase in antibody titers could be observed in mice injected with HBV-HCV chimeras.

The intracellular targeting of $\mathrm{HCV}$ core protein to specific cellular compartments was recently evaluated as a way to optimize vaccine responses [115]. A wild-type core expressing plasmid was compared with plasmids expressing either the core sequence in fusion with the ubiquitin gene or with the signal sequence and transmembrane domain of the murine lysosome-associated membrane protein (mLAMP-1). The principal aim of the ubiquitin fusion was to improve degradation of core in a proteasomedependent fashion in order to optimize core-derived peptide transport to the MHC class I pathway and, as a consequence, the resulting CTL activity. This strategy was very efficient when used for the nucleoprotein of the lymphocytic choriomeningitis virus model [116]. Similarly, the mLAMP-1 fusion was realized to target the core protein to the intracellular endosomal/lysosomal pathway, particularly the MHC-class-II-enriched compartments. These organelles are mainly present in antigen presenting cells, and it may be indeed interesting to try and target the expression of a vaccine antigen to these compartments. LAMP type fusions have recently been shown to efficiently enhance $\mathrm{T}$ cell proliferative response, CTL activity and antibody production in the case of antigens such as papillomavirus HPV-16 E7 [117] or HIV gp 160 [118]. Nevertheless, in contrast to these previously reported studies, Vidalin et al. [116] did not observe any improvement in the induction of either proliferative CTL or antibody-based immune responses specific to $\mathrm{HCV}$ core. The reasons for this failure are not clear.

$\mathrm{Hu}$ et al. [112] compared BALB/c mice immunized twice with a core-encoding plasmid or primed with the plasmid and boosted with a recombinant purified core protein (amino acids 1-164). Although a protein boost following priming with DNA was shown to induce earlier seroconversion rates as well as higher in vitro CD4+ $\mathrm{T}$ cell proliferative responses, CTL activity remained comparable to that observed following DNA vaccination alone.

\section{Role of Core in HCV Diagnosis}

There are three common assay procedures used to diagnose $\mathrm{HCV}$ infection.

These include anti-HCV antibody assay, HCV-RNA detection and recently introduced HCV core antigen assay. Reports from various studies indicate the presence of HCV core protein in nearly $80-92 \%$ of patients positive with anti-HCV antibody [77, 119-121]. At the same time, the concordance between HCV core and HCV-RNA was noted up to $93-95 \%[77,121]$. In few studies, HCV core assay has been reported to be less sensitive than antiHCV or HCV-RNA assay, though all those reports found it to be more specific as compared to these techniques [121]. Total HCV core antigen quantification is an accurate and precise indirect marker of $\mathrm{HCV}$ replication in $\mathrm{HCV}$-infected patients. However, HCV core assay cannot detect HCV replication for HCV-RNA value below 20,000 $\mathrm{IU} / \mathrm{ml}$ [122]. Despite several merits of HCV core assay over HCV-RNA detection by PCR, core assay has been reported to be less sensitive in different studies [123]. Whereas the sensitivity of HCV-RNA assay was found to be $99 \%$ that of HCV core assay was noted as 98\% [124]. Tanaka et al. [125] also reported a sensitivity of $98 \%$ for the core assay. It was comparable to that of HCV-RNA. However, Zanetti et al. [123] found only $82 \%$ sensitivity of core as compared to that of HCV-RNA assay. In fact, more studies are needed to further authenticate the beneficial effect of HCV core estimation over HCV-RNA detection for the diagnosis of HCV infection. 


\section{Future Aspects of HCV Core}

It is very interesting to study more aspects of $\mathrm{HCV}$ core protein now, particularly when complete cell culture systems are available [126-129]. The role of the core protein can be investigated more extensively for the process re- lated to $\mathrm{HCV}$ entry, replication and virion production. The culture system may also help in developing antiviral agents targeting different stages of virus cycle, and these may prove to be potential therapeutic agents. How HCV core protein acts or plays a role in all these phenomena may now be possible to study and understand.

\section{References}

$>1$ Koike K, Tsutsumi T, Fujie H, Yoshizumi S, Moriya K: Molecular mechanism of viral hepatocarcinogenesis. Oncology 2002;62:2937

-2 Brinster C, Inchauspe G: DNA vaccine for hepatitis-C virus. Immunology 2001;44: 143-153.

$>3$ Alter HJ: To C or not to C: these are the questions. Blood 1995;85:1681-1695.

$>4$ WHO: Hepatitis C: global prevalence. Wkly Epidemiol Rec 1997;72:341-348.

$\checkmark 5$ Drazan KE: Molecular biology of hepatitis-C infection. Liver Transpl 2000;6:396-406.

$\checkmark 6$ Choo QL, Kuo G, Weiner AJ, Overby L, Bradley DW, Houghton M: Isolation of a cDNA clone derived from a blood-borne non-A, non-B viral hepatitis genome. Science $1989 ; 244: 359-362$.

7 Choo Q-L, Richman K, Han J, Berger K, Lee C, Dong C, Gallegos D, Coit D, Medina-Selly A, Barr P, Weiner A, Bradley D, Kuo G, Houghton M: Genetic organization and diversity of the hepatitis-C virus. Proc Natl Acad Sci USA 1991;88:2451-2455.

$\checkmark 8$ Simmonds P, Holmes EC, Cha TA, Chan SW, McOmish F, Irvine B, Beall E, Yap PL, Kolberg J, Urdea MS: Classification of hepatitis- $C$ virus into six major genotypes and a series of subtypes by phylogenetic analysis of the NS-5 region. J Gen Virol 1993;74:23912399.

-9 Bukh J, Miller R, Purcell R: Genetic Heterogenicity of hepatitis-C virus: Quasispecies and genotypes. Semin Liver Dis 1995;15:4163.

10 Wang C, Sarnow P, Siddiqui A: A conserved helical element is essential for internal initiation of translation of hepatitis- $C$ virus RNA. J Virol 1994;68:7301-7307.

-11 Yanagi M, St Claire M, Emerson SU, Purcell $\mathrm{RH}$, Bukh J: In-vivo analysis of the $3^{\prime}$ untranslated region of the hepatitis- $\mathrm{C}$ virus after in-vitro mutagenesis of an infectious cDNA clone. Proc Natl Acad Sci USA 1999; 96:2291-2295.

12 Houghton M: Hepatitis C viruses; in Fields BN, Knipe DM, Howley PM (eds): Fields Virology, 3rd ed. Philadelphia, LippincottRaven, 1996, pp 1035-1058.

13 Lin C, Pragai BM, Grakoui A, Xu J and Rice CM: Hepatitis-C virus NS3 serine proteinase: trans-cleavage requirements and processing kinetics. J Virol 1994;68:5063-5073.
14 Santolini E, Migliaccio G, Monica NL: Biosynthesis and biochemical properties of the hepatitis-C virus core protein. J Virol 1994; 68:3631-3641.

15 Ray RB, Lagging LM, Meyer K, Steele R, Ray $\mathrm{R}$ : Transcriptional regulation of cellular and viral promoters by the hepatitis- $\mathrm{C}$ virus core protein. Virus Res 1995;37:209-220.

16 McLauchlan J: Properties of the hepatitis-C virus core protein: a structural protein that modulates cellular processes. J Viral Hepat 2000;7:2-14

-17 Kunkel M, Lorinezi M, Rijinbrand R, Lemon SM, Watowich SJ: Self-assembly of nucleocapsid-like particles from recombinant hepatitis-C virus core protein. J Virol 2001;75 2119-2129.

18 Kunkel M, Watowich SJ: Conformational changes accompanying self-assembly of the hepatitis-C virus core protein. Virology 2002;294:239-245.

19 Fan Z, Yang QR, Twu JS, Sherker AH: Specific in-vitro association between the hepatitis- $\mathrm{C}$ viral genome and core protein. J Med Virol 1999;59:131-134.

20 Tanaka Y, Shimoike T, Ishii K, Suzuki R, Suzuki T, Ushijima H, Matsuura Y, Miyamura $\mathrm{T}$ : Selective binding of hepatitis- $\mathrm{C}$ virus core protein to synthetic oligonucleotides corresponding to the $5^{\prime}$ untranslated region of the viral genome. Virology 2000;270:229-236.

21 Matsumoto M, Hwang SB, Jeng KS, Zhu N, Lai MM: Homotypic interaction and multimerization of hepatitis- $\mathrm{C}$ virus core protein Virology 1996;218:43-51.

22 Nolandt O, Kern V, Muller H, Pfaff E, Theilmann L, Welker R, Krausslich HG: Analysis of hepatitis- $\mathrm{C}$ virus core protein interaction domains. J Gen Virol 1997;78:1331-1340.

23 Lo SY, Selby MJ, Ou JH: Interaction between hepatitis- $\mathrm{C}$ virus core protein and $\mathrm{E} 1$ envelope protein. J Virol 1996;70:5177-5182.

24 Ravaggi A, Natoli G, Primi D, Albertini A, Levero M, Cariani J: Intracellular localization of full-length and truncated hepatitis-C virus core protein expressed in mammalian cells. J Hepatol 1994;20:833-836.

-25 Suzuki R, Matsuura Y, Suzuki T, Ando A, Chiba J, Harada S, Saito I, Miyamura T: Nuclear localization of the truncated hepatitis$\mathrm{C}$ virus core protein with its hydrophobic C terminus deleted. J Gen Virol 1995;76:5361.
26 Zhu N, Khoshnan A, Schneider R, Matsumoto M, Dennert G, Wase C, Lai MM: Hepatitis- $\mathrm{C}$ virus core protein binds to the cytoplasmic domain of tumor necrosis factor (TNF) receptor 1 and enhances TNF-induced apoptosis. J Virol 1998;72:3691-3697.

27 Chen CM, You LR, Hwang LH, Lee YH: Direct interaction of hepatitis- $\mathrm{C}$ virus core protein with the cellular lymphotoxin-beta receptor modulates the signal pathway of the lymphotoxin-beta receptor J Virol 1997;71: 9417-9426.

28 Mamiya N, Worman HJ: Hepatitis-C virus core protein binds to a DEAD box RNA helicase. J Biol Chem 1999;274:15751-15756.

29 Owslanka AM, Patel AH: Hepatitis-C virus core protein interacts with a human DEAD box protein DDX3. Virology 1999;257:330340 .

30 Hseih TY, Matsumoto M, Chou HC, Schneider R, Hwang SB, Lee AS, Lai MM: Hepatitis- $\mathrm{C}$ virus core protein interacts with heterogeneous nuclear ribonucleoprotein $\mathrm{K}$. J Biol Chem 1998;273:17651-17659.

-31 Wang F, Yoshida I, Takamatsu M, Ishido S, Fujita T, Oka K, Hotta H: Complex formation between hepatitis- $\mathrm{C}$ virus core protein and p21Wat/Cip1/Sid.1. Biochem Biophys Res Commun 2000;273:479-484.

32 Lu W, Lo S, Chen M, Wu K, Fung YKT, Ou J: Activation of $\mathrm{p} 53$ tumor suppressor by Hepatitis-C virus core protein. Virology 1999; 264:134-141.

33 Jin DY, Wang HL, Zhou Y, Chun AC, Kibler KV, Hou YD, Kung H, Jeang KT: Hepatitis-C virus core protein-induced loss of LZIP function correlates with cellular transformation. EMBO J 2000;19:729-740.

34 Kato N, Yoshida H, Kioko Ono-Nita S, Kato J, Goto T, Otsuka M, Lan K, Matsushima K, Shiratori Y, Omata M: Activation of intracellular signaling by hepatitis B and C viruses, $\mathrm{C}$-viral core is the most potent signal inducer. Hepatology 2000;32:405-412.

-35 Naganuma A, Nozaki A, Tanaka T, Sugiyama K, Takagi H, Mori M, Shimotoohno K, Kato N: Activation of the interferon inducible 2'-5'-oligoadenylate synthetase gene by hepatitis- $C$ virus core protein. J Virol 2000; 74:8744-8750 
-36 Otsuka M, Kato N, Lan KH, Yoshida H, Kato J, Goto T, Shiratori Y, Omata M: Hepatitis-C virus core protein enhances p53 function through augmentation of DNA binding affinity and transcriptional ability. J Biol Chem 2000;275:34122-34130.

-37 Hahn CS, Cho YG, Kang BS, Lester IM, Hahn YS: The HCV core protein acts as a positive regulator of fas-mediated apoptosis in a human lymphoblastoid T-cell line. Virology 2000;276:127-137.

-38 Ray RB, Meyer K, Ray R: Suppression of apoptotic cell death by hepatitis- $\mathrm{C}$ virus core protein. Virology 1996;226:176-182.

-39 Marusawa H, Hijikata M, Chiba T, Shimotohno K: Hepatitis- $\mathrm{C}$ virus core protein inhibits Fas- and tumor necrosis factor alpha-mediated apoptosis via NF-kappaB activation. J Virol 1999;73:4713-4720.

-40 Moriya K, Yotsuyanagi H, Shintani Y, Fujie $\mathrm{H}$, Ishibashi K, Matsuura Y, Miyamura T, Koike K: Hepatitis- $\mathrm{C}$ virus core protein induces hepatic steatosis in transgenic mice. J Gen Virol 1997;78:1527-1531.

-41 Yamaguchi A, Tazuma S, Nishioka T, Ohishi W, Hyogo H, Nomura S, Chayama K: Hepatitis- $\mathrm{C}$ virus core protein modulates fatty acid metabolism and thereby causes lipid accumulation in the liver. Dig Dis Sci 2005;50: 1361-1371.

-42 Goh PY, Tan YJ, Lim SP, Lim SG, Tan YH, Hong WJ: The hepatitis-C virus core protein interacts with NS5A and activates its caspase mediated proteolytic cleavage. Virology 2001;290:224-236.

-43 Moradpour D, Englert C, Wakita T, Wands JR: Characterization of cell lines allowing tightly regulated expression of hepatitis-C virus core protein. Virology 1996;222:5163.

-44 Barba G, Harper F, Harada T, Kohara M, Goulinet S, Matsuura Y, Eder G, Schaff Z, Chapman MJ, Miyamura T, Brechot C: Hepatitis- $\mathrm{C}$ virus core protein shows a cytoplasmic localization and associates to cellular lipid storage droplets. Proc Natl Acad Sci USA 1997;94:1200-1205.

-45 Satoh S, Hirota M, Noguchi T, Hijikata M, Handa H, Shimitohno K: Cleavage of Hepatitis- $\mathrm{C}$ virus nonstructural protein. Virology 2000;229:68-76.

-46 Ruggleri A, Harada T, Matsuura Y, Miyamura T: Sensitization to Fas-mediated apoptosis by hepatitis-C virus core protein. Virology 1997;229:68-76.

$\checkmark 47$ Roulston A, Marcellus RC, Branton PE: Viruses and apoptosis. Ann Rev Microbiol 1999;53:577-628.

-48 Liu Q, Tackney C, Bhat RA, Prince AM, Zhang P: Regulated processing of hepatitis$\mathrm{C}$ virus core protein is linked to subcellular localization. J Virol 1997;71:657-662.
49 Liao QJ, Ye LB, Timani KA, She YL, Yang XJ, Ye L, Wu ZH: Hepatitis-C virus non-structural $5 \mathrm{~A}$ protein can enhance full-length core protein-induced nuclear factor-kappaB activation. World J Gastroenterol 2005;11 6433-6439.

50 Kountouras J, Zavos C, Chatzopoulos D: Apoptosis in hepatitis-C. J Viral Hepat 2003; 10:335-342.

51 Scaffidi C, Fulda S, Srinivasan A, Friesen C, Li F, Tomaseli KJ, Debatin, KM, Krammer PH, Peter ME: Two CD95 (APO-1/Fas) signaling pathways. EMBO J 1998;17:16751687.

52 Porteu A, Henrion A, Bouscary D, Varlet P, Rouquet N, Molina T: Bcl-2 protects from lethal hepatic apoptosis induced by an anti-Fas antibody in mice. Nat Med 1996;2:80-86.

53 Adams JM, Cory S: The Bcl-2 protein family: arbiters of cell survival. Science 1998;281: 1322-1326.

54 Chinnaiyan AM, Orth K, O’Rourke K, Duan H, Poiner GG, Dixit VM: Molecular ordering of the cell death pathway. Bcl-2 and Bcl$\mathrm{xL}$ function upstream of the CED-3-like apoptotic protease. J Biol Chem 1996;271: 4573-4576.

55 Erhardt P, Cooper GM: Activation of the CPP 32 apoptone protease by distinct signaling pathways with differential sensitivity to Bcl-xL. J Biol Chem 1996;271:17601-17604.

56 Shimiz S, Eguchi Y, Kamiike W, Matsuda H, Tsujimoto Y: Bcl-2 blocks loss of mitochondrial membrane potential while ICE inhibitors act at a different step during inhibition of death induced by respiratory chain inhibitors. Oncogene 1996;13:21-29.

57 You LR, Chen CM, Lee YHW: Hepatitis-C virus core protein enhances NF-kappaB signal pathway triggering by lymphotoxin-beta receptor ligand and tumor necrosis factor al pha. J Virol 1999;73:1672-1681.

58 Yoshida H, Kato N, Shiratori Y, Otsuka M, Meeda S, Kato J, Omata M: Hepatitis-C virus core protein activates nuclear factor kappaBdependent signaling through tumor necrosis factor receptor-associated factor. J Biol Chem 2001;276:16399-16405.

59 Wang CY, Mayo MW, Korneluk RG, Goeddel DV, Baldwin AS Jr: NF-kappaB antiapoptosis. Induction of TRAF1 and TRAF2 and c-IAP1 and c-IAP2 to suppress caspase-8 activation. Science 1998;281:1680-1683.

60 Wu MX, Ao Z, Prasad KV, Wu R, Schlossman SF: IEX-1L, an apoptosis inhibitor involved in NF-kappaB-mediated cell survival. Science 1998;281:998-1001.

61 Grumont RJ, Rourke IJ, Gerondakis S: Reldependent induction of A1 transcription is required to protect $B$ cells from antigen receptor ligation-induced apoptosis. Genes Dev 1999;13:400-411.

-62 Hettmann T, DiDonato J, Karin M, Leiden JM: An essential role for nuclear factor kappaB in promoting double positive thymocyte apoptosis. J Exp Med 1999;189:145-158.
63 Cerny A, Chisari FV: Pathogenesis of chronic hepatitis-C Immunological features of hepatic injury and viral persistence. Hepatology 1999;30:595-601.

64 Matsuura K, Kimura Y, Miyamura ST, Koike $\mathrm{K}$ : The core protein of hepatitis- $\mathrm{C}$ virus induces hepatocellular carcinoma in transgenic mice. Nat Med 1998;4:1065-1067.

65 Soguero C, Joo M, Chianese-Bullock KA, Nguyen DT, Tung K, Hahn YS: Hepatitis-C virus core protein leads to immune suppression and liver damage in a transgenic murine model. J Virol 2002;76:9345-9354.

66 Kimball P, Verbeke S, Shiffman M: HCV core protein augments cyclosporine immunosuppression. Transplant Proc 2005;37: 652-653.

67 Gehring S, Gregory SH, Kuzushita N, Wands JR: Type 1 interferon augments DNA-based vaccination against hepatitis- $C$ virus core protein. J Med Virol 2005;75:249-257.

68 Chou AH, Tsai HF, Wu YY, Hu CY, Hwang LH, Hsu PI, Hsu PN: Hepatitis-C virus core protein modulates TRAIL-mediated apoptosis by enhancing Bid cleavage and activation of mitochondria apoptosis signaling pathway. J Immunol 2005;174:2160-2166.

69 Li W, Li J, Tyrrell DL, Agrawal B: Expression of hepatitis- $\mathrm{C}$ virus-derived core or NS3 antigens in human dendritic cells leads to induction of pro-inflammatory cytokines and normal T-cell stimulation capabilities. J Gen Virol 2006;87:61-72.

70 Sundstrom S, Ota S, Dimberg LY, Masucci MG, Bergqvist A: Hepatitis- $C$ virus core protein induces an anergic state characterized by decreased interleukin- 2 production and perturbation of mitogen-activated protein kinase responses. J Virol 2005;79:22302239.

71 Takahashi M, Saito H, Higashimoto M, Atsukawa $\mathrm{K}$, Ishii $\mathrm{H}$ : Benefit of hepatitis- $\mathrm{C}$ virus core antigen assay in prediction of therapeutic response to interferon and ribavirin combination therapy. J Clin Microbiol 2005; 43:186-191.

72 Cooper S, Erikson AL, Adams EJ, Kansopon J, Weiner AJ, Chen DY, Houghton M, Parham P, Walker CM: Analysis of a successful immune response against hepatitis- $\mathrm{C}$ virus. Immunity 1999;10:439-449.

73 Missale G, Bertoni R, Lamonaca V, Valli A, Massari M, Mori C, Rumi MG, Houghton M, Fiaccadori F, Ferrari C: Different clinical behaviors of acute hepatitis $\mathrm{C}$ virus infection are associated with different vigor of the anti-viral cell-mediated immune response. J Clin Invest 1996;98:706-714

74 Chang KM, Gruener NH, Southwood S, Sidney J, Pape GR, Chang FV, Sette A: Identification of HLA-A3 and B7-restricted CTL responses hepatitis- $\mathrm{C}$ virus in patients with acute and chronic hepatitis-C. J Immunol 1999;162:1156-1164. 
-75 Sabile A, Perlemuter G, Bono F, Kohara K, Demaugre F, Kotex M, Matsuura Y, Miyamura T, Brechot C, Barba G: Hepatitis-C virus core protein binds to apolipoprotein All and its secretion is modulated by fibrates. Hepatology 1999;30:1064-1076.

- 76 Hijikata M, Mizushima H, Akagi T, Mori S, Kakkiuchi N, Kato N, Tanga T, Kimura K, Shimotohno K: Two distinct proteinase activities required for the processing of a putative nonstructural precursor protein of hepatitis-C virus. J Virol 1999;67:4665-4675.

-77 Kanto T, Hayashi N, Takehara T, Hagiwara $\mathrm{H}$, Mita E, Nate M, Kasahara A, Fusamoto H, Kamada T: Buoyant density of hepatitis virus recovered from infected hosts: two different features in sucrose equipment density-gradient centrifugation related to degree of liver inflammation. Hepatology 1994;19:296302.

-78 Aoyagi K, Ohue C, Iida K, Kimura T, Tanaka E, Kiyosawa K, Yen S: Development of a simple and highly sensitive enzyme immunoassay for hepatitis-C virus core antigen. J Clin Microbiol 1999;37:1802-1808.

-79 Urushihara A, Sodeyama T, Matsumoto A, Tanaka E. Changes in antibody titres to hepatitis- $\mathrm{C}$ virus following interferon therapy for chronic infection. J Med Virol 1994;42: 348-356.

-80 Ray RB, Meyer K, Steele R, Shrivastava A, Aggarwal BB, Ray R: Inhibition of tumor necrosis factor (TNF-alpha) mediated apoptosis by hepatitis-C virus. J Biol Chem 1998; 273:2256-2259.

81 Large M, Kittlesen D, Hahn Y: Suppression of host immune response by the core protein of hepatitis-C virus. Possible implications for hepatitis- $\mathrm{C}$ virus persistence. J Immunol 1999;162:931-938.

-82 Matsumoto M, Hsieh TY, Zhu N, Vanarsdale T, Hwang SB, Jeng KS, Gorbalenya AE, Lo SY, Ou JH, Ware CF, Lai MMC: Hepatitis-C virus core protein interacts with the cytoplasmic tail of lymphotoxin- $\beta$ receptor. J Virol 1997;71:1301-1309.

83 Kroemer G: Mitochondrial control of apoptosis: an overview. Biochem Soc Symp 1999; 66:1-15.

84 Machida K, Tsukiyama-Kohara K, Seike E, Tone S, Shibasaki F, Shimizu M, Takahashi H, Hayashi Y, Funata N, Taya C, Yonekawa $\mathrm{H}$, Kohara M: Inhibition of cytochrome c release in Fas-mediated signalling pathway in transgenic mice induced to express hepatitis-C viral proteins. J Biol Chem 2001;276: 12140-12146.

-85 Moriya K, Fujie H, Shintani Y, Yotsuyanagi $\mathrm{H}$, Tsutsumi T, Ishibashi K, Matsuura $\mathrm{Y}$, Kimura S, Miyamura T, Koike K: The core protein of hepatitis- $\mathrm{C}$ virus induces hepatocellular carcinoma in transgenic mice. Nat Med 1998;4:1065-1067.
86 Rizzuto R, Pinton P, Carrington W, Fay FS, Fogarty KE, Lifshitz LM, Tuft RA, Pozzan T: Close contacts with the endoplasmic reticulum as determinants of mitochondrial $\mathrm{Ca}^{2+}$ responses. Science 1998;280:1763-1766.

87 Okuda M, Li K, Beard MR, Showalter LA, Schole F, Lemon SM, Weinman SA: Mitochondrial injury, oxidative stress, and antioxidant gene expression are induced by hepatitis- $C$ virus core protein. Gastroenterology 2002;122:366-375.

88 Majander A, Finel M, Wikstrom M: Diphenyleneiodonium inhibits reduction of ironsulfur clusters in the mitochondrial NADHubiquinone oxidoreductase (complex I). J Biol Chem 1994;269:21037-21042.

89 Baley SM, Pietsch EC, Cunningham CC: Ethanol stimulates the production of reactive oxygen species at mitochondrial complexes I and III. Free Radic Biol Med 1992;27: 891-900.

90 Cai J, Jones DP: Mitochondrial redox signaling during apoptosis. J Bioenerg Biomembr 1999;31:327-334.

-91 Moriya K, Nakagawa K, Santa T, Shintani Y, Fujie H, Miyoshi H, Tsutsumi T, Miyazawa T, Ishibashi K, Horie T, Imai K, Todoroki T, Kimura S, Koike K: Oxidative stress in the absence of inflammation in a mouse model for hepatitis-C virus-associated hepatocarcinogenesis. Cancer Res 2001;61:43654370.

92 Factor VM, Laskowska D, Jensen MR, Woltach JT, Popescu NC, Thorgeirsson SS: Vitamin E reduces chromosomal damage and inhibits hepatic tumor formation in a transgenic mouse model. Proc Natl Acad Sci USA 2000;97:2196-2201.

93 Lau JYN, Krawczynski K, Negro F, Gonzalez-Peralta RP: In situ detection of hepatitisC virus: a critical appraisal. J Hepatol 1996; 24:48-53.

94 Shimizu YK, Feinstone SM, Kohara M, Purcell RH, Yoshikura H: Hepatitis-C virus: detection of intracellular virus particles by electron microscopy. Hepatology 1996;23: 205-209.

95 Agnello V, Knight AG, Munchmore E: Detection of widespread hepatocyte infection in chronic hepatitis-C. Hepatology 1998;28: 573-584.

96 Hoofnagle JH: Hepatitis-C: The clinical spectrum of disease. Hepatology 1997;26: $15 S-20 S$.

97 Lerat A, Honda M, Beard MR, Loesch K, Sun J, Yang Y, Okuda M, Gosert R, Xiao SY, Weinman SA, Lemon SM: Steatosis and liver cancer in transgenic mice expressing the structural and nonstructural proteins of hepatitis-C virus. Gastroenterology 2002; 122:352-365.
-98 Adinolfi LE, Durante-Mangoni E, Zampino R, Ruggiero G: Review article: hepatitis- $\mathrm{C}$ virus-associated steatosis - pathogenic mechanisms and clinical implications. Aliment Pharmacol Ther 2005;22(suppl 2): 52-55.

\$9 Marreto JA, Fontana RJ, Su GL, et al: NAFLD may be a common underlying liver disease in patients with HCC in the United States. Hepatology 2002;36:1349-1354.

100 Lee MN, Jung EY, Kwun HJ, et al: Hepatitis$\mathrm{C}$ virus core protein represses the $\mathrm{p} 21$ promotor thorough inhibition of a TGF-beta pathway. J Gen Virol 2002;83:2145-2151.

101 Kwun HJ, Jang KL: Dual effects of hepatitis- $\mathrm{C}$ virus Core protein on the transcription of cyclin-dependent kinase inhibitor p21 gene. J Viral Hepat 2003;10:249-255.

102 Yamanaka T, Kodama T, Doi T: Subcellular localization of HCV CORE protein regulates its ability for p53 activation and p21 suppression. Biochem Biophys Res Commun 2002;294:528-534.

103 Zakut R, Givol D: The tumor suppression function of p21Waf is contained in its $\mathrm{N}$ terminal half ('half-WAF'). Oncogene 1995;11:393-395.

104 Varaklioti A, Vassilaki N, Georgopoulou U, Mavromara P: Alternate translation occurs within the core coding region of the hepatitis-C viral genome. J Biol Chem 2002;277: 17713-17721.

105 Benard J, Douc-Rasy S, Ahomadegbe JC: TP53 family members and human cancers. Hum Mutat 2003;21:182-191.

106 Davis GL: Hepatitis-C virus genotypes and quasispecies. Am J Med 1999;107:21S-26S.

107 Alisi A, Giambartolomei S, Cupelli F, et al: Physical and functional interaction between HCV core protein and the different p73 isoforms. Oncogene 2003;22:25732580.

108 Iwata K, Wakita T, Okumura A, Yoshioka K, Takayanagi M, Wands J, Kakumu S: Interferon gamma production by peripheral blood lymphocytes to hepatitis- $\mathrm{C}$ virus core protein in chronic hepatitis- $\mathrm{C}$ infection. Hepatology 1995;22:1057-1064.

109 Lasarte JJ, Garcia-Granero G, Lopez A, Casares N, Garcia N, Civeira MP, BorrasCuesta F, Prieto J: Cellular immunity to hepatitis- $C$ virus core protein and the response to interferon in patients with chronic hepatitis-C. Hepatology 1998;28:815822.

110 Nelson DR, Marousis CG, Davis GL, Rice CM, Wong J, Houghton M, Lau JYN: The role of hepatitis- $\mathrm{C}$ virus-specific cytotoxic T lymphocytes in chronic hepatitis-C. J Immunol 1997;158:1473-1481.

-111 Lagging LM, Meyer K, Hoft D, Houghton M, Belshe RB, Ray R: Immune responses to plasmid DNA encoding the hepatitis- $\mathrm{C}$ virus core protein. J Virol 1995;69:58595863. 
-112 Hu GJ, Wang RYH, Han DS, Alter HJ, Shih WK: Characterization of the humoral and cellular immune responses against hepatitis-C virus core induced by DNA-based immunization. Vaccine 1999;17:3160-3170.

113 Geissler M, Tokushige K, Wakita T, Zurawski VR, Wands JR: Differential cellular and humoral immune responses to $\mathrm{HCV}$ core and HBV envelope proteins after genetic immunization using chimeric constructs. Vaccine 1998;16:857-867.

114 Inchauspe G, Vitvitski L, Major ME, Jung G, Spengeler U, Maisonnas M, Trepo C: Plasmid DNA expressing a secreted or a nonsecreted form of hepatitis- $\mathrm{C}$ virus nucleocapsid: Comparative studies of antibody and T-helper responses following genetic immunization. DNA Cell Biol 1997; 16:182-195.

- 115 Major ME, Vitvitski L, Mink MA, Schleef M, Whalen RG, Trepo C, Inchauspe G: DNA based immunization with chimeric vectors for the induction of immune responses against the hepatitis- $\mathrm{C}$ virus nucleocapsid. J Virol 1995;69:5798-5805.

116 Vidalin O, Tanaka E, Spengler U, Trepo C, Inchauspe $\mathrm{G}$ : Targeting hepatitis- $\mathrm{C}$ virus core protein for MHC1 or MHC II presentation does not enhance induction of immune responses to DNA vaccination. DNA Cell Biol 1999;18:611-621.

117 Rodriguez F, Zhang J, Whitton J: DNA immunization: Ubiquitination of a viral protein enhances cytotoxic T-lymphocyte induction and antiviral protection but abrogates antibody induction. J Virol 1997; 71:8497-8503.
118 Chen C, Ji H, Suh K, Choti M, Pardoll D, Wy $\mathrm{T}$ : Gene-gun mediated DNA vaccination induces antitumor immunity against human papillomarvirus type 16 E7-expressing murine tumours in the liver and lungs. Gene Ther 1999;6:1972-1981.

119 Ruff A, Guarnieri F, Stageley-O’Carroll K, Siliciano R, August J: The enhanced immune response to the HIV gp 160-LAMP chimeric gene product targeted to the lysosome membrane protein trafficking pathway. J Biol Chem 1997;272:8671-8678.

120 Tanaka T, Lau JYN, Mizokami M, et al: Simple fluorescent enzyme immunoassay for detection and quantification of hepatitis-C viremia. J Hepatol 1995;23:742-745.

121 Kashiwakuma T, Hasegawa A, Kajita T, et al: Detection of hepatitis-C virus specific core protein in serum of patients by a sensitive fluorescence enzyme immunoassay (FEIA). J Immunol Methods 1996;190:7989.

122 Arduino JM, Stuver SO, Spiegelman D, et al: Assessment of markers of hepatitis- $\mathrm{C}$ virus infection in a Japanese adult. J Infect Dis 2001;184:1229-1235.

123 Zanetti AR, Romano I, Brunetto M, Colombo M, Belati G, Tackney C: Total HCV core antigen assay: a new marker of hepatitis- $\mathrm{C}$ viremia for monitoring the progress of therapy. J Med Virol 2003;70:27-30.
124 Megali Bouvier A, Patel K, Dahari H, Beaucourt S, et al. Clinical utility of total HCV core antigen quantification: A new indirect marker of HCV replication. Hepatology 2002;36:211-218.

125 Tanaka E, Ohue C, Aoyagi K, Yamanguchi K, Yagi S, Kiyosawa K, Alter HJ: Evaluation of a new enzyme immunoassay for hepatitis- $\mathrm{C}$ virus (HCV) core antigen with clinical sensitivity approximating that of genomic amplification of HCV RNA. Hepatology 2001;32:388-393.

126 Lindenbach BD, Rice CM: Unravelling hepatitis- $\mathrm{C}$ virus replication from genome to function. Nature 2005;436:933-938.

127 Lindenbach BD, Evans MJ, Syder AJ, Wolk B, Tellinghuisen TL, Liu CC, Maruyama T, Hynes RO, Burton DR, McKeating JA, Rice $\mathrm{CM}$ : Complete replication of hepatitis- $\mathrm{C}$ virus in cell culture. Science 2005;309:623626.

128 Zhong J, Gastaminza P, Cheng G, Kapadia S, Kato T, Burton DR, Wieland SF, Uprichard SL, Wakita T, Chisari FV: Robust hepatitis-C virus infection in-vitro. Proc Natl Acad Sci USA 2005;102:9294-9299.

129 Wakita T, Pietschmann T, Kato T, Date T, Miyamoto M, Zhao Z, Murthy K, Habermann A, Krausslich HG, Mizokami M, Bartenschlager R, Liang TJ: Production of infectious hepatitis- $C$ virus in tissue culture from a cloned viral genome. Nat Med 2005;11:791-796. 